\title{
Evaluation of leaching potential of tebuthiuron using bioindicator plants
}

\section{Estudo da lixiviação do herbicida tebuthiuron com plantas bioindicadoras}

\author{
Antonio Carlos da Silva Junior ${ }^{*}$ (D), Clebson Gomes Gonçalves ${ }^{1}$ (D), \\ Juliana Roberta Gobi Queiroz ${ }^{2}$, Dagoberto Martins ${ }^{1}(\mathbb{D}$
}

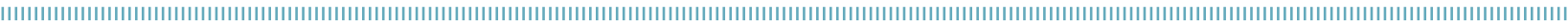

\begin{abstract}
The last destination of most herbicides used in agricultural systems is the soil. This is a dynamic interaction; herbicides can remain in the soil solution or be carried through the soil profile, reaching the water table. The objective of this work was to evaluate the leaching potential of the tebuthiuron herbicide using bioindicator plants grown in an Oxisol of sandy loam texture and in an Entisol of clay texture, after the occurrence of natural rainfall events. A complete randomized experimental design was used, in a $3 \times 8$ factorial arrangement, with four replications. The treatments consisted of three accumulated natural rainfall depths $(30-40,60-80$, and $100-120 \mathrm{~mm})$ and eight soil profile layers $(0-3,3-6,6-9,9-12,12-15$, $15-20,20-25$, and $25-30 \mathrm{~cm}$ ). Soil samples were collected after the tebuthiuron herbicide application -750 for clayey soil, and $600 \mathrm{~g} \mathrm{ha}^{-1}$ for the sandy loam soil —and the rainfall events. PVC pipes with length of $30 \mathrm{~cm}$ and diameter of $15 \mathrm{~cm}$ were introduced into the soil profile for sampling. The pipes with soil columns were carefully removed by digging around them, to maintain the soil original integrity during collection and, subsequently, cut longitudinally for sowing the bioindicator species - cucumber (Cucumis sativus L.), and lettuce (Lactuca sativa L.). Then, the phytotoxicity in the bioindicator plants grown in these soils were evaluated at 5 , 7,10 , and 12 days after sowing, using a grading scale of 0 to $100 \%$. The mobility of the tebuthiuron herbicide was low in both soils, regardless of the rainfall depth, and the cucumber was the most suitable plant species to use as a bioindicator.
\end{abstract}

KEYWORDS: Herbicide dynamics; soil profile; soil class; weeds.
RESUMO: O solo é o destino final da maioria dos herbicidas utilizados no sistema agrícola e, sendo esta relação dinâmica, eles podem permanecer na solução ou ser carregados no perfil do solo, podendo atingir o lençol freático. O objetivo deste trabalho foi avaliar o potencial de lixiviaçáo do herbicida tebuthiuron por meio de plantas bioindicadoras e após a ocorrência de precipitaçōes pluviométricas naturais, em solos com texturas franco arenoso (Latossolo Vermelho-Amarelo) e argiloso (Neossolo Litólico). O delineamento experimental foi o inteiramente casualizado em um esquema fatorial $3 \times 8 \mathrm{com}$ quatro repetiçóes, sendo três níveis de precipitação pluviométrica (30-40, 60-80 e 100-120 mm) e oito de profundidade do perfil do solo (0-3, 3-6, 6-9, 9-12, 12-15, 15-20, 20-25 e 25-30 cm). As coletas das amostras ocorreram após a aplicação do herbicida tebuthiuron nas doses de 750 e $600 \mathrm{~g} \mathrm{ha}^{-1}$ para o solo argiloso e arenoso, respectivamente, e posterior acúmulo das precipitaçóes. Para a coleta das amostras foram introduzidas, no perfil do solo, colunas de PVC com $30 \mathrm{~cm}$ de altura e $15 \mathrm{~cm}$ de diâmetro. As colunas foram retiradas cuidadosamente escavando-se ao seu redor, mantendo a integridade original do solo durante a coleta. Posteriormente, as colunas foram separadas com corte longitudinal, para a semeadura das espécies bioindicadoras pepino (Cucumis sativus L.) e alface (Lactuca sativa L.). Para as avaliaçóes das plantas bioindicadoras nas colunas, adotou-se a escala de notas de 0 a 100\% de fitotoxicidade, aos 5, 7, 10 e 12 dias após a semeadura. A mobilidade do herbicida tebuthiuron mostrou-se reduzida em ambos os tipos de solo estudado, independentemente da precipitaçáo pluvial, e as plantas de pepino mostraram-se mais adequadas para serem utilizadas como espécie bioindicadora.

PALAVRAS-CHAVE: Dinâmica de herbicidas; perfil do solo; tipo de solo; plantas daninhas. 


\section{INTRODUCTION}

Tebuthiuron is a non-selective systemic herbicide of the substituted-urea group that is used to control broad-leaf, and woody weeds, and is recommended for sugarcane crops. It acts at the reaction center of photosystem II by binding to a specific site of the $\mathrm{Qb}$ quinone, on protein $\mathrm{D} 1$, blocking the transport of electrons from the Qa quinone to the Qb (OLIVEIRA JÚNIOR, 2011). The half-life of tebuthiuron is 360 days, and its solubility in water is high $\left(2,500 \mathrm{mg} \mathrm{L}^{-1}\right.$ at $\left.25^{\circ} \mathrm{C}\right)$, with Koc of $80 \mathrm{~mL} \mathrm{~g}^{-1}$. The vapor pressure of the tebuthiuron is $2 \times 10^{-6}$ at $20^{\circ} \mathrm{C}$, and its dissociation constant $(\mathrm{pKa})$ is 1.2 , which favors its mobility in the soil profile (RODRIGUES; ALMEIDA, 2011).

The tebuthiuron herbicide can be applied at pre-emergence and post-emergence. It is absorbed from the soil by the roots and accumulated in the shoot of the plants; however, it can cause serious environmental impact due to the possibility of contamination of surface and subsurface waters (PIRES et al., 2005). Predicting the dynamics and interactions of pesticides such as tebuthiuron in the soil depends on reliable sorption equilibrium constants and sorption coefficient to organic matter, according to the clay type and content of the soil (DORNELAS DE SOUZA et al., 2001).

PIRES et al. (2008) found most of the herbicide tebuthiuron - applied to a Red-Yellow Argissolo (Ultisol) in the soil solution, due to its organic matter content and low CEC, showing low sorption capacity.

According to CHRISTOFFOLETI; LÓPEZ-OVEJERO (2005), tebuthiuron herbicide has high solubility in water (low Koc), which is recommended for sugarcane crops in drought periods. This may explain the good results of tebuthiuron in controlling weeds in sugarcane crops, even with presence of straws (INOUE et al., 2007; NEGRISOLI et al., 2007). However, its intensive use in large areas can contribute to environmental problems. GOMES et al. (2006) showed that some soil characteristics - low carbon content, high hydraulic conductivity, and low clay content - commonly found in Neossolo Quartzarênico (Psamment), make the average tebuthiuron leaching 6.7-fold higher than the average found in Red Latosol (Oxisol).

This herbicide has residual activity in the soil. According to TOFOLI et al. (2009), evaluating the dynamics of this substituted-urea herbicide in agricultural systems in which it is used is important due to the great use of tebuthiuron for weed control and scarcity of data on the dynamics of this herbicide in different application conditions. Soil is the last destination of most agricultural pesticides applied in agriculture; they can remain in the soil solution or be carried through the soil profile. The mobility of the herbicide molecules depends on the amount absorbed by plants and the amount that remains in the soil solution. This affects the last destination of the herbicide in the environment, thus, understanding its dynamics is increasingly important.
The objective of this work was to evaluate the leaching potential of the tebuthiuron herbicide using bioindicator plants grown in soils of different textures, after the occurrence of natural rainfalls.

\section{MATERIAL AND METHODS}

The experiment was conducted in an Oxisol of sandy loam texture and in an Entisol of clay texture, according to SERGIO et al. (2005), in the Lageado Experimental Station area

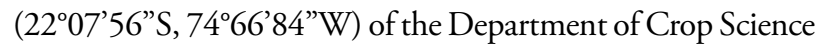
of the School of Agriculture, Botucatu, São Paulo, Brazil.

The experiment was conducted using a complete randomized design, in a $3 \times 8$ factorial arrangement with four replications. The treatments consisted of three accumulated natural rainfall depths (ARD) before sampling (31, 62, and $114 \mathrm{~mm}$ for the clayey soil; and 36,65 , and $116 \mathrm{~mm}$ for the sandy loam soil) and eight soil profile layers (0-3, 3-6, 6-9, 9-12, $12-15,15-20,20-25$, and $25-30 \mathrm{~cm}$ ).

The study was implemented and conducted in two phases: field and greenhouse conditions. The chemical and granulometric properties of the soil were analyzed in samples taken from the $0-10,10-20$, and $20-30 \mathrm{~cm}$ layers of the two soils (Tables 1 and 2).

In the field phase, PVC pipes with length of $30 \mathrm{~cm}$ and diameter of $15 \mathrm{~cm}$ were introduced into the soil profile for sampling. Then, the herbicide tebuthiuron was applied. The herbicide rate used was according to technical recommendations for each type of soil: $750 \mathrm{~g} \mathrm{ha}^{-1}$ for the clayey soil, and $600 \mathrm{~g}$ $\mathrm{ha}^{-1}$ for the sandy loam soil. The herbicide was applied to the top of the pipes (on the soil surface) maintaining the application bar at $50 \mathrm{~cm}$ from the soil surface, and speed of $1 \mathrm{~m} \mathrm{~s}^{-1}$, using a $\mathrm{CO}_{2}$ pressurized backpack sprayer with XR11002VS flat jet nozzles (Teejet ${ }^{\circledast}$, Wheaton, USA), with working pressure of $196 \mathrm{kPa}$, and volume representing $200 \mathrm{~L} \mathrm{ha}^{-1}$.

Rainfalls occurring after the herbicide application were monitored daily during the experiment using rain gauges installed in the experimental areas. The withdrawing of the PVC pipes with soil columns occurred when the ARD reached $31 \mathrm{~mm}$ (clayey soil) and $36 \mathrm{~mm}$ (sandy loam soil), at 4 days after application (DAA); when the ARD reached $62 \mathrm{~mm}$ (clay soil) and $66 \mathrm{~mm}$ (sandy loam soil), at $11 \mathrm{DAA}$; and when the ARD reached $114 \mathrm{~mm}$ (clay soil) and $116 \mathrm{~mm}$ (sandy loam soil), at 16 DAA. Therefore, all samples were within the pre-established rainfall depths for this factor $-30-40,60-80$, and $100-120 \mathrm{~mm}$.

The PVC pipes with soil columns were carefully removed by digging around them, to maintain the soil original integrity during collection. The lower edge of the pipes was supported to retain the soil with fine screens after collection.

The soil columns were separated into two halves through a longitudinal cut using a metal wire and a galvanized plate placed 
between them. Subsequently, the bioindicator species cucumber (Cucumis sativus L.) (OLIVEIRA et al., 1999), and lettuce (Lactuca sativa L.) (DEUBER et al., 2004) were sown, expecting the emergence of 25 plants of each species per soil column.

The phytotoxicity in the bioindicator plants was evaluated at $5,7,10$, and 12 days after sowing, using a grading scale of 0 to $100 \%$ (SBCPD, 1995), in which 0\% represents plants with no injury, and $100 \%$ represents dead plants.

The data were converted to $y=$ sine $\operatorname{arc}(\operatorname{root}(\mathrm{x} / 100))$ and subjected to analysis of variance by the $\mathrm{F}$ test, and the means of the treatments were compared by the Tukey test at $5 \%$ of probability.

\section{RESULTS AND DISCUSSION}

The data obtained in the visual evaluation of phytotoxicity in cucumber plants (Table 3) showed the leaching potential of tebuthiuron herbicide in the three accumulated natural rainfall depths (ARD). The evolution of the phytotoxicity in the bioindicator plants evaluated at $5,7,10$, and 12 DAS showed that residues of tebuthiuron can reach depths of up to $12 \mathrm{~cm}$ in the profile of the clayey soil, regardless of the ARD. Even with low rainfall depths after the herbicide application, such as one for example of $31 \mathrm{~mm}$, the herbicide reached the $6-9 \mathrm{~cm}$ layer from the first evaluation (5 DAS); the herbicide reached the 9-12 cm layer at 10 and 12 DAS with ARD of 62 and $114 \mathrm{~mm}$, respectively.

SOUZA et al. (2008) had similar results with more than $70 \%$ of the applied herbicide (tebuthiuron) found up to $30 \mathrm{~cm}$ of depth. The mobility of the tebuthiuron in the soil is necessary for the herbicide to reach the seed bank and weed roots for absorption to occur; however, the potential of groundwater pollution due to this low mobility in the soil is highly unlikely (EMMERICH, 1985).

The data obtained in the visual evaluation of phytotoxicity in lettuce plants showed the phytotoxic effect of tebuthiuron at 5 and 7 DAS (Table 4). Tebuthiuron residues reached the 3-6 cm layer from the lowest ARD $(31 \mathrm{~mm})$ at 5 DAS and the 9-12 cm layer at 7 DAS. The mobility of tebuthiuron in clayey soils was confirmed in the evaluations at 10 and 12 DAS (Table 4), with phytotoxicity in lettuce plants in the same layer $(9-12 \mathrm{~cm})$, regardless of the ARD.

BOEIRA et al. (2003) also found low leaching potential for the tebuthiuron herbicide; this was probably because the dystroferric Red Latosol (Oxisol) used presented high levels of organic matter and clay, which caused the apparent retention of all tebuthiuron residues in the soil surface layer, with no leaching to the layers deeper than $0-10 \mathrm{~cm}$. According to SOUZA et al. (2008), physical-chemical characteristics of clayey soils are important factors for low vertical percolation

Table 1. Chemical analysis results of the soil samples collected from different depths in both experiments after the application of tebuthiuron. Botucatu, São Paulo, 2013.

\begin{tabular}{|c|c|c|c|c|c|c|c|c|c|c|c|}
\hline \multirow{2}{*}{ Soil } & \multirow{2}{*}{$\begin{array}{l}\text { Depth } \\
\text { (cm) }\end{array}$} & \multirow{2}{*}{$\begin{array}{c}\mathrm{pH} \\
\mathrm{CaCl}_{2}\end{array}$} & \multirow{2}{*}{$\begin{array}{l}\text { O.M. } .^{3} \\
\mathrm{~g} \mathrm{dm}^{-3}\end{array}$} & \multirow{2}{*}{$\begin{array}{c}P_{\text {resine }} \\
\mathbf{m g ~ d m}^{-3}\end{array}$} & \multicolumn{5}{|c|}{ mmolc $\mathrm{dm}^{-3}$} & \multirow{2}{*}{$\mathrm{CEC}^{5}$} & \multirow{2}{*}{$\begin{array}{l}\text { BS }^{6} \\
\text { (\%) }\end{array}$} \\
\hline & & & & & K & $\mathrm{Ca}$ & Mg & $\mathrm{H}+\mathrm{Al}$ & $\mathrm{SC}^{4}$ & & \\
\hline \multirow{3}{*}{ Entisol $^{1}$} & $0-10$ & 4.8 & 22 & 11 & 1.6 & 33 & 14 & 46 & 48 & 94 & 51 \\
\hline & $10-20$ & 4.7 & 21 & 10 & 1.8 & 29 & 14 & 50 & 44 & 94 & 47 \\
\hline & $20-30$ & 4.7 & 25 & 9 & 2.1 & 30 & 15 & 51 & 47 & 98 & 48 \\
\hline \multirow{3}{*}{ Oxisol $^{2}$} & $0-10$ & 4.1 & 14 & 17 & 0.9 & 4 & 2 & 39 & 7 & 46 & 15 \\
\hline & $10-20$ & 4.1 & 13 & 19 & 0.4 & 4 & 2 & 34 & 7 & 40 & 16 \\
\hline & $20-30$ & 4.1 & 12 & 18 & 0.6 & 5 & 3 & 38 & 8 & 46 & 18 \\
\hline
\end{tabular}

'Clayish soil; ${ }^{2}$ medium sandy soil; ${ }^{3}$ organic matter; ${ }^{4}$ sum of cations; ${ }^{5}$ cation exchange capacity; ${ }^{6}$ base saturation.

Table 2. Granulometric analysis of two soils sampled at different depths after treatment with tebuthiuron. Botucatu, São Paulo, 2013.

\begin{tabular}{|c|c|c|c|c|c|c|}
\hline \multirow{2}{*}{ Particle size $\left(\mathrm{g} \mathrm{kg}^{-1}\right)$} & \multicolumn{3}{|c|}{ Entisols ${ }^{1}$ - depth $(\mathrm{cm})$} & \multicolumn{3}{|c|}{ Oxisols ${ }^{2}-$ depth $(\mathrm{cm})$} \\
\hline & $0-10$ & $10-20$ & $20-30$ & $0-10$ & $10-20$ & $20-30$ \\
\hline Clay & 436 & 449 & 460 & 193 & 189 & 186 \\
\hline Silt & 163 & 163 & 152 & 37 & 36 & 35 \\
\hline Coarse sand & 100 & 100 & 100 & 315 & 693 & 303 \\
\hline Fine sand & 301 & 288 & 288 & 455 & 482 & 477 \\
\hline Total sand & 401 & 388 & 388 & 770 & 775 & 780 \\
\hline Soil Texture & Clayish & Clayish & Clayish & Medium & Medium & Medium \\
\hline
\end{tabular}

'Clayish soil; ${ }^{2}$ medium sandy soil. 
of the tebuthiuron herbicide. Thus, the groundwater in these soils presents less risk of contamination.

However, leaching potential can increase due to the great amount of this herbicide used in sugarcane crops even in clayey soils, and its long residual effect in the soil.

Despite the low concentrations of tebuthiuron found in groundwaters by GOMES et al. (2001), they confirmed that this herbicide can reach groundwaters, and possibly this concentration can increase due to the favorable environmental conditions for the preservation of this molecule in deeper layers low temperature, low biological activity, and absence of light.

Regarding the sandy loam soil, the tebuthiuron reached only the soil surface layer $(0-3 \mathrm{~cm})$ after an ARD of $36 \mathrm{~mm}$ at 5 DAS when using cucumber as indicator plants. However,

Table 3. Phytotoxicity percentage in cucumber plants after the application of tebuthiuron to a clayish-textured soil under different rainfall amounts. Botucatu, São Paulo, 2013.

\begin{tabular}{|c|c|c|c|c|c|c|c|c|c|c|c|}
\hline \multirow{4}{*}{$\begin{array}{l}\text { Soil profile } \\
(\mathrm{cm}) \\
0-3\end{array}$} & \multicolumn{11}{|c|}{ Accumulated rainfall } \\
\hline & \multicolumn{6}{|c|}{5 DAS $^{1}$} & \multicolumn{5}{|c|}{7 DAS } \\
\hline & \multicolumn{2}{|l|}{$31 \mathrm{~mm}$} & \multicolumn{2}{|l|}{$62 \mathrm{~mm}$} & \multicolumn{2}{|l|}{$114 \mathrm{~mm}$} & \multicolumn{2}{|l|}{$31 \mathrm{~mm}$} & $62 \mathrm{~mm}$ & \multicolumn{2}{|l|}{$114 \mathrm{~mm}$} \\
\hline & $7.5(0.28)^{2}$ & $\mathrm{aA}$ & $7.0(0.27)$ & $\mathrm{aA}$ & $3.7(0.19)$ & bA & $24.2(0.51)$ & $\mathrm{aA}$ & $23.4(0.50)$ & $12.5(0.36)$ & bA \\
\hline $3-6$ & $2.5(0.16)$ & $\mathrm{aB}$ & $2.3(0.15)$ & $\mathrm{aB}$ & $1.2(0.11)$ & $\mathrm{aB}$ & $11.2(0.34)$ & $\mathrm{aB}$ & $11.0(0.34)$ & $4.5(0.1)$ & $b B$ \\
\hline $6-9$ & $2.5(0.16)$ & $\mathrm{aB}$ & $2.1(0.15)$ & $\mathrm{aB}$ & $1.0(0.10)$ & $\mathrm{aB}$ & $2.5(0.16)$ & $\mathrm{aC}$ & $2.0(0.14)$ & $0.0(0.00)$ & $\mathrm{bC}$ \\
\hline $9-12$ & $0.0(0.00)$ & $\mathrm{aC}$ & $0.0(0.00)$ & $\mathrm{aC}$ & $0.0(0.00)$ & $\mathrm{aB}$ & $0.0(0.00)$ & $\mathrm{aD}$ & $0.0(0.00)$ & $0.0(0.00)$ & $\mathrm{aC}$ \\
\hline $12-15$ & $0.0(0.00)$ & $\mathrm{aC}$ & $0.0(0.00)$ & $\mathrm{aC}$ & $0.0(0.00)$ & $\mathrm{aB}$ & $0.0(0.00)$ & $\mathrm{aD}$ & $0.0(0.00)$ & $0.0(0.00)$ & $\mathrm{aC}$ \\
\hline $15-20$ & $0.0(0.00)$ & $\mathrm{aC}$ & $0.0(0.00)$ & $\mathrm{aC}$ & $0.0(0.00)$ & $\mathrm{aB}$ & $0.0(0.00)$ & $\mathrm{aD}$ & $0.0(0.00)$ & $0.0(0.00)$ & $\mathrm{aC}$ \\
\hline $20-25$ & $0.0(0.00)$ & $\mathrm{aC}$ & $0.0(0.00)$ & $\mathrm{aC}$ & $0.0(0.00)$ & $\mathrm{aB}$ & $0.0(0.00)$ & $\mathrm{aD}$ & $0.0(0.00)$ & $0.0(0.00)$ & $\mathrm{aC}$ \\
\hline $25-30$ & $0.0(0.00)$ & $\mathrm{aC}$ & $0.0(0.00)$ & $\mathrm{aC}$ & $0.0(0.00)$ & $\mathrm{aB}$ & $0.0(0.00)$ & $\mathrm{aD}$ & $0.0(0.00)$ & $0.0(0.00)$ & $\mathrm{aC}$ \\
\hline \multicolumn{3}{|l|}{ F Rainfall (R) } & \multicolumn{4}{|c|}{$11.908^{* *}$} & \multicolumn{5}{|c|}{46.651 ** } \\
\hline \multicolumn{3}{|l|}{ F Profile $(P)$} & \multicolumn{4}{|c|}{$12.469^{* *}$} & \multicolumn{5}{|c|}{$56.140 * *$} \\
\hline \multicolumn{3}{|l|}{$F(R) X(P)$} & \multicolumn{4}{|c|}{$4.053^{* *}$} & \multicolumn{5}{|c|}{$16.657^{* *}$} \\
\hline \multicolumn{3}{|l|}{ C.V. (\%) } & \multicolumn{4}{|c|}{169.1} & \multicolumn{5}{|c|}{81.3} \\
\hline \multicolumn{3}{|l|}{ d.m.s. (R) } & \multicolumn{4}{|c|}{0.08} & \multicolumn{5}{|c|}{0.08} \\
\hline \multicolumn{3}{|l|}{ d.m.s. (P) } & & O. & 11 & & & & 0.11 & & \\
\hline & & & & & $\mathrm{Accl}$ & umula & ted rainfall & & & & \\
\hline $\begin{array}{l}\text { Soil profile } \\
(\mathrm{cm})\end{array}$ & & & $10 \mathrm{DAS}$ & & & & & & 12 DAS & & \\
\hline & $31 \mathrm{~mm}$ & & $62 \mathrm{~mm}$ & & $114 \mathrm{~mm}$ & & $31 \mathrm{~mm}$ & & $62 \mathrm{~mm}$ & $114 \mathrm{~mm}$ & \\
\hline $0-3$ & $71.2(1.0)^{2}$ & bA & $90.0(1.25)$ & $\mathrm{aA}$ & $73.7(1.03)$ & $a b A$ & $99.5(1.50)$ & $\mathrm{aA}$ & $97.5(1.41)$ & $98.0(1.43)$ & $\mathrm{aA}$ \\
\hline $3-6$ & $65.5(0.94)$ & $\mathrm{aA}$ & $62.5(0.91)$ & $\mathrm{aB}$ & $65.5(0.94)$ & $\mathrm{aA}$ & $100.0(1.57)$ & $\mathrm{aA}$ & $95.2(1.36) \quad a b A$ & $86.2(1.19)$ & bAB \\
\hline $6-9$ & $36.2(0.65)$ & $b B$ & $51.2(0.80)$ & $a b B$ & $65.2(0.94)$ & $\mathrm{aA}$ & $65.5(0.94)$ & $\mathrm{aB}$ & $69.0(0.98)$ & $78.2(1.09)$ & $\mathrm{aB}$ \\
\hline $9-12$ & $10.0(0.32)$ & $\mathrm{aC}$ & $10.0(0.32)$ & $\mathrm{aC}$ & $15.0(0.40)$ & $\mathrm{aB}$ & $29.0(0.57)$ & $\mathrm{aC}$ & $21.2(0.48)$ & $25.0(0.52)$ & $\mathrm{aC}$ \\
\hline $12-15$ & $0.0(0.00)$ & $\mathrm{aC}$ & $0.0(0.00)$ & $\mathrm{aC}$ & $0.0(0.00)$ & $\mathrm{aC}$ & $0.0(0.00)$ & $\mathrm{aD}$ & $0.0(0.00)$ & $0.0(0.00)$ & $\mathrm{aD}$ \\
\hline $15-20$ & $0.0(0.00)$ & $\mathrm{aC}$ & $0.0(0.00)$ & $\mathrm{aC}$ & $0.0(0.00)$ & $\mathrm{aC}$ & $0.0(0.00)$ & $\mathrm{aD}$ & $0.0(0.00)$ & $0.0(0.00)$ & $\mathrm{aD}$ \\
\hline $20-25$ & $0.0(0.00)$ & $\mathrm{aC}$ & $0.0(0.00)$ & $\mathrm{aC}$ & $0.0(0.00)$ & $\mathrm{aC}$ & $0.0(0.00)$ & $\mathrm{aD}$ & $0.0(0.00)$ & $0.0(0.00)$ & $\mathrm{aD}$ \\
\hline $25-30$ & $0.0(0.00)$ & $\mathrm{aC}$ & $0.0(0.00)$ & $\mathrm{aC}$ & $0.0(0.00)$ & $\mathrm{aC}$ & $0.0(0.00)$ & $\mathrm{aD}$ & $0.0(0.00)$ & $0.0(0.00)$ & $\mathrm{aD}$ \\
\hline F Rainfall (R) & & & & 1.5 & $33^{\text {ns }}$ & & & & $0.474^{\mathrm{ns}}$ & & \\
\hline F Profile (P) & & & & $137 . C$ & $54^{* *}$ & & & & $203.057^{* *}$ & & \\
\hline$F(R) X(P)$ & & & & 1.2 & $5^{\text {ns }}$ & & & & $0.754^{* *}$ & & \\
\hline C.V. (\%) & & & & 36 & .4 & & & & 29.5 & & \\
\hline d.m.s. (R) & & & & 0. & 24 & & & & 0.27 & & \\
\hline d.m.s. (P) & & & & 0. & 31 & & & & 0.35 & & \\
\hline
\end{tabular}

Means within a column followed by the same upper-case letter and within a line followed by the same small case letter are not significantly different at the $5 \%$ probability level according to Tukey's test. 'DAS: days after sowing; ${ }^{2}$ data in parentheses were transformed using the equation $y=\operatorname{arc} \sin [\operatorname{root}(x / 100)]$; * significant at level $(p<0.05) ;{ }^{* *}$ significant at level $(p<0.01)$. 
the herbicide reached the 6-9 $\mathrm{cm}$ layer with ARD of $65 \mathrm{~mm}$ and $116 \mathrm{~mm}$, the 3-6 cm layer at 7 DAS, and the $6-9 \mathrm{~cm}$ layer in the other ARD (Table 5).

The leaching potential of the tebuthiuron in the sandy loam soil was confirmed at 10 and 12 DAS, with the herbicide reaching the 6-9 $\mathrm{cm}$ layer after an ARD of $36 \mathrm{~mm}$, the $9-12 \mathrm{~cm}$ layer after an ARD of $65 \mathrm{~mm}$, and the 12-15 cm layer after an ARD of $116 \mathrm{~mm}$ (Table 5). Therefore, the tebuthiuron mobility in the sandy loam soil profile depended on the ARD.

MATALLO et al. (2004) evaluated the risk of groundwater contamination with the tebuthiuron herbicide through lysimeter studies and found risk of leaching, especially in sandy soils, due to dispersion and convection factors of the soils. These researchers evaluated the total amount of leached

Table 4. Phytotoxicity percentage in lettuce plants after the application of tebuthiuron to a clayish-textured soil under different rainfall amounts. Botucatu, São Paulo, 2013.

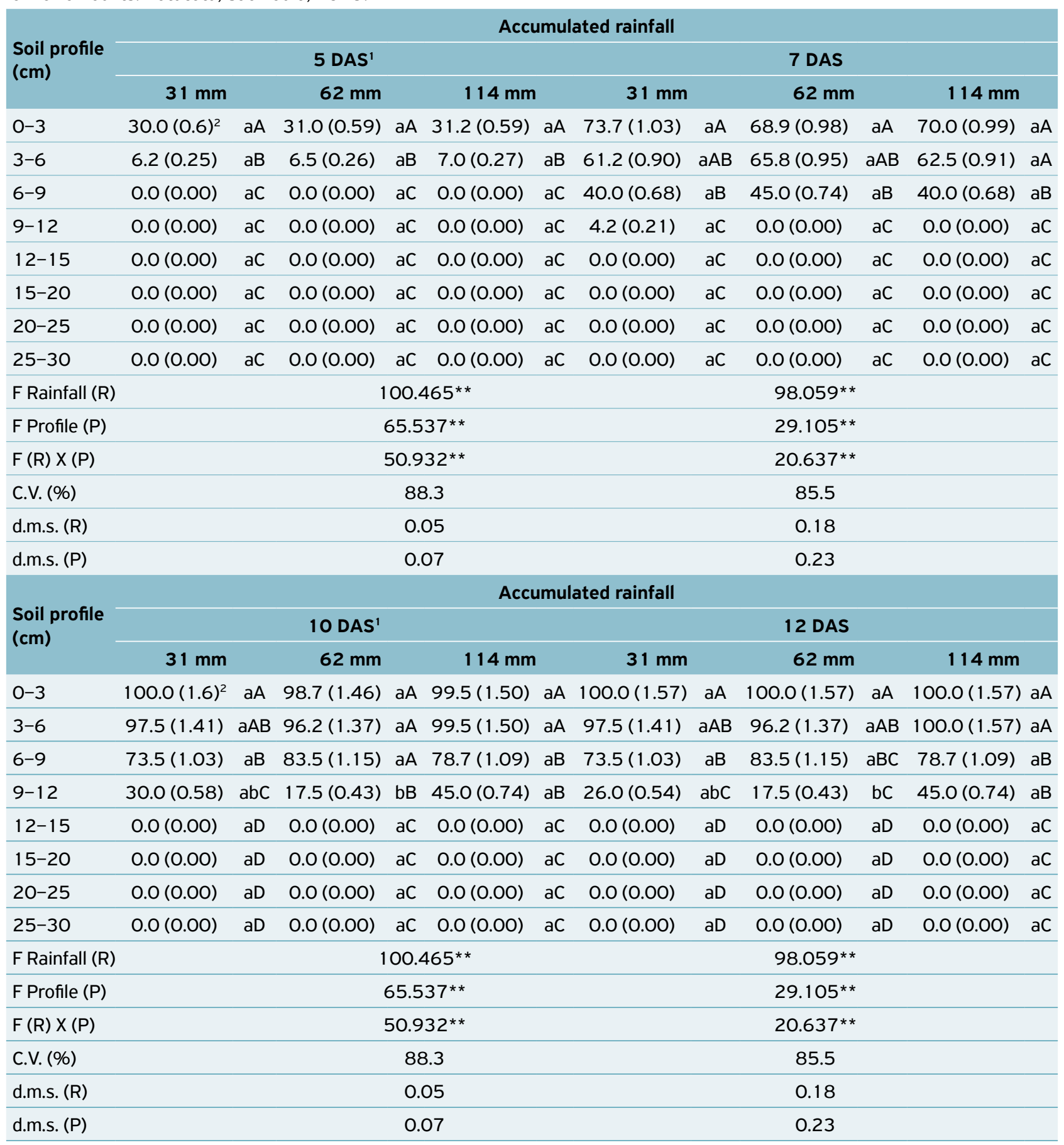

Means within a column followed by the same upper-case letter and within a line followed by the same small case letter are not significantly different at the $5 \%$ probability level according to Tukey's test. 'DAS: days after sowing; ${ }^{2}$ data in parentheses were transformed using the equation $y=\operatorname{arc} \sin [\operatorname{root}(x / 100)]$; ${ }^{*}$ significant at level $(p<0.05) ;{ }^{*}$ significant at level $(p<0.01)$. 
herbicide in a Neossolo Quartzarênico (Psamment) and found that these results may be due to the dispersion and diffusion of the herbicide in micropores, associated with the differential water mobility through the pores of this sandy soil.

The percolation period of most agrochemicals through the profile of Neossolo Quartzarênicos is affected by their lower field capacity; the estimated percolation of the tebuthiuron through the first $120 \mathrm{~cm}$ of a Neossolo Quartzarênico was approximately $54 \%$ (SPADOTTO et al., 2002). In the present study, the herbicide tebuthiuron showed similar leaching potential in the Red-Yellow Latosol (Oxisol).

The herbicide caused no phytotoxicity in lettuce plants at 5 and 7 DAS, except with an ARD of $116 \mathrm{~mm}$, when it was found up to the 3-6 cm layer (Table 6). This denotes

Table 5. Phytotoxicity percentage in cucumber plants after the application of tebuthiuron to a medium sandy-textured soil under different rainfall amounts. Botucatu, São Paulo, 2013.

\begin{tabular}{|c|c|c|c|c|c|c|c|c|c|c|c|c|}
\hline \multirow{4}{*}{$\begin{array}{l}\begin{array}{l}\text { Soil } \\
\text { profile } \\
(\mathrm{cm})\end{array} \\
0-3\end{array}$} & \multicolumn{12}{|c|}{ Accumulated rainfall } \\
\hline & \multicolumn{6}{|c|}{5 DAS $^{1}$} & \multicolumn{6}{|c|}{7 DAS } \\
\hline & \multicolumn{2}{|l|}{$36 \mathrm{~mm}$} & \multicolumn{2}{|l|}{$65 \mathrm{~mm}$} & \multicolumn{2}{|c|}{$116 \mathrm{~mm}$} & \multicolumn{2}{|l|}{$36 \mathrm{~mm}$} & \multicolumn{2}{|l|}{$65 \mathrm{~mm}$} & \multicolumn{2}{|l|}{$116 \mathrm{~mm}$} \\
\hline & $5.0(0.23)^{2}$ & $\mathrm{aA}$ & $3.7(0.19)$ & $\mathrm{aA}$ & $4.7(0.22)$ & $\mathrm{aA}$ & $13.7(0.38)$ & bA & $48.0(0.77)$ & $\mathrm{aA}$ & $40.0(0.68)$ & $\mathrm{aB}$ \\
\hline $3-6$ & $0.0(0.00)$ & $\mathrm{bB}$ & $1.2(0.11)$ & $\mathrm{aA}$ & $1.5(0.12)$ & $\mathrm{aA}$ & $30.0(0.58)$ & bA & $44.5(0.73)$ & $\mathrm{aA}$ & $50.0(0.79)$ & $\mathrm{aA}$ \\
\hline $6-9$ & $0.0(0.00)$ & $\mathrm{bB}$ & $3.7(0.19)$ & $\mathrm{aA}$ & $4.0(0.20)$ & $\mathrm{aA}$ & $0.0(0.00)$ & $\mathrm{bB}$ & $40.0(0.68)$ & $\mathrm{aA}$ & $45.0(0.74)$ & $\mathrm{aAB}$ \\
\hline $9-12$ & $0.0(0.00)$ & $\mathrm{aB}$ & $0.0(0.00)$ & $\mathrm{aB}$ & $0.0(0.00)$ & $\mathrm{aB}$ & $0.0(0.00)$ & $\mathrm{aB}$ & $0.0(0.00)$ & $\mathrm{aB}$ & $0.0(0.00)$ & $\mathrm{aA}$ \\
\hline $12-15$ & $0.0(0.00)$ & $\mathrm{aB}$ & $0.0(0.00)$ & $\mathrm{aB}$ & $0.0(0.00)$ & $\mathrm{aB}$ & $0.0(0.00)$ & $\mathrm{aB}$ & $0.0(0.00)$ & $\mathrm{aB}$ & $0.0(0.00)$ & $\mathrm{aA}$ \\
\hline $15-20$ & $0.0(0.00)$ & $\mathrm{aB}$ & $0.0(0.00)$ & $\mathrm{aB}$ & $0.0(0.00)$ & $\mathrm{aB}$ & $0.0(0.00)$ & $\mathrm{aB}$ & $0.0(0.00)$ & $\mathrm{aB}$ & $0.0(0.00)$ & $\mathrm{aA}$ \\
\hline $20-25$ & $0.0(0.00)$ & $\mathrm{aB}$ & $0.0(0.00)$ & $\mathrm{aB}$ & $0.0(0.00)$ & $\mathrm{aB}$ & $0.0(0.00)$ & $\mathrm{aB}$ & $0.0(0.00)$ & $\mathrm{aB}$ & $0.0(0.00)$ & $\mathrm{aA}$ \\
\hline $25-30$ & $0.0(0.00)$ & $\mathrm{aB}$ & $0.0(0.00)$ & $\mathrm{aB}$ & $0.0(0.00)$ & $\mathrm{aB}$ & $0.0(0.00)$ & $\mathrm{aB}$ & $0.0(0.00)$ & $\mathrm{aB}$ & $0.0(0.00)$ & $\mathrm{aA}$ \\
\hline \multicolumn{3}{|l|}{ F Rainfall (R) } & \multicolumn{4}{|c|}{$6.677^{* *}$} & \multicolumn{6}{|c|}{$8.757^{* *}$} \\
\hline \multicolumn{3}{|l|}{ F Profile $(P)$} & \multicolumn{4}{|c|}{$6.446^{* *}$} & \multicolumn{6}{|c|}{$22.257^{* *}$} \\
\hline \multicolumn{3}{|l|}{$F(R) X(P)$} & \multicolumn{4}{|c|}{$2.813^{* *}$} & \multicolumn{6}{|c|}{$7.508^{* *}$} \\
\hline \multicolumn{3}{|l|}{ C.V. (\%) } & \multicolumn{4}{|c|}{236.6} & \multicolumn{6}{|c|}{165.8} \\
\hline \multicolumn{3}{|l|}{ d.m.s. (R) } & \multicolumn{4}{|c|}{0.09} & \multicolumn{6}{|c|}{0.09} \\
\hline \multicolumn{3}{|l|}{ d.m.s. (P) } & & & 12 & & & & 0.11 & & & \\
\hline Soil & & & & & $\mathrm{Acc}$ & umula & ted rainfall & & & & & \\
\hline profile & & & $10 \mathrm{DAS}$ & & & & & & 12 DAS & & & \\
\hline & $36 \mathrm{~mm}$ & & $65 \mathrm{~mm}$ & & $116 \mathrm{~mm}$ & & $36 \mathrm{~mm}$ & & $65 \mathrm{~mm}$ & & $116 \mathrm{~mm}$ & \\
\hline $0-3$ & $81.2(1.1)^{2}$ & $\mathrm{aA}$ & $80.0(1.11)$ & $\mathrm{aA}$ & $40.0(0.68)$ & bA & $99.0(1.47)$ & $\mathrm{aA}$ & $99.7(1.52)$ & $\mathrm{aA}$ & $96.2(1.37)$ & $\mathrm{aA}$ \\
\hline $3-6$ & $60.0(0.89)$ & $\mathrm{aA}$ & $76.2(1.06)$ & $\mathrm{aA}$ & $37.5(0.66)$ & bA & $84.2(1.16)$ & $a b B$ & $90.5(1.26)$ & $\mathrm{aB}$ & $65.2(0.94)$ & $\mathrm{bB}$ \\
\hline $6-9$ & $23.7(0.51)$ & bB & $62.5(0.91)$ & $\mathrm{aA}$ & $42.5(0.71)$ & $a b A$ & $39.0(0.67)$ & $\mathrm{bC}$ & $82.5(1.14)$ & $\mathrm{aB}$ & $52.5(0.81)$ & $\mathrm{bB}$ \\
\hline $9-12$ & $0.0(0.00)$ & $b c$ & $15.0(0.40)$ & $\mathrm{aB}$ & $38.7(0.67)$ & $\mathrm{aA}$ & $0.0(0.00)$ & $\mathrm{bD}$ & $16.2(0.41)$ & $\mathrm{aC}$ & $41.2(0.70)$ & $\mathrm{aC}$ \\
\hline $12-15$ & $0.0(0.00)$ & $\mathrm{aC}$ & $0.0(0.00)$ & $\mathrm{aB}$ & $0.0(0.00)$ & $\mathrm{aB}$ & $0.0(0.00)$ & $b D$ & $0.0(0.00)$ & $b D$ & $11.2(0.34)$ & $\mathrm{aD}$ \\
\hline $15-20$ & $0.0(0.00)$ & $\mathrm{aC}$ & $0.0(0.00)$ & $\mathrm{aB}$ & $0.0(0.00)$ & $\mathrm{aB}$ & $0.0(0.00)$ & $\mathrm{aD}$ & $0.0(0.00)$ & $\mathrm{aD}$ & $0.0(0.00)$ & $\mathrm{aE}$ \\
\hline $20-25$ & $0.0(0.00)$ & $\mathrm{aC}$ & $0.0(0.00)$ & $\mathrm{aB}$ & $0.0(0.00)$ & $\mathrm{aB}$ & $0.0(0.00)$ & $\mathrm{aD}$ & $0.0(0.00)$ & $\mathrm{aD}$ & $0.0(0.00)$ & $\mathrm{aE}$ \\
\hline $25-30$ & $0.0(0.00)$ & $\mathrm{aC}$ & $0.0(0.00)$ & $\mathrm{aB}$ & $0.0(0.00)$ & $\mathrm{aB}$ & $0.0(0.00)$ & $\mathrm{aD}$ & $0.0(0.00)$ & $\mathrm{aD}$ & $0.0(0.00)$ & $\mathrm{aE}$ \\
\hline F Rainfall (R) & & & & 6.36 & $65^{* *}$ & & & & $6.403^{* *}$ & & & \\
\hline F Profile (P) & & & & 133. & 419 ** & & & & $241.174^{*}$ & & & \\
\hline$F(R) X(P)$ & & & & 8.4 & $87^{* *}$ & & & & $6.353^{* *}$ & & & \\
\hline C.V. (\%) & & & & & 5.7 & & & & 27.3 & & & \\
\hline d.m.s. (R) & & & & & 21 & & & & 0.22 & & & \\
\hline d.m.s. (P) & & & & & 28 & & & & 0.29 & & & \\
\hline
\end{tabular}

Means within a column followed by the same upper-case letter and within a line followed by the same small case letter are not significantly different at the $5 \%$ probability level according to Tukey's test. 'DAS; days after sowing; ${ }^{2}$ data in parentheses were transformed using the equation $y=\operatorname{arc} \sin [\operatorname{root}(x / 100)]$; ${ }^{*}$ significant at level $(p<0.05) ;{ }^{*}$ significant at level $(p<0.01)$. 
Table 6. Phytotoxicity percentage in lettuce plants after the application of tebuthiuron to a medium sandy-textured soil under different rainfall amounts. Botucatu, São Paulo, 2013.

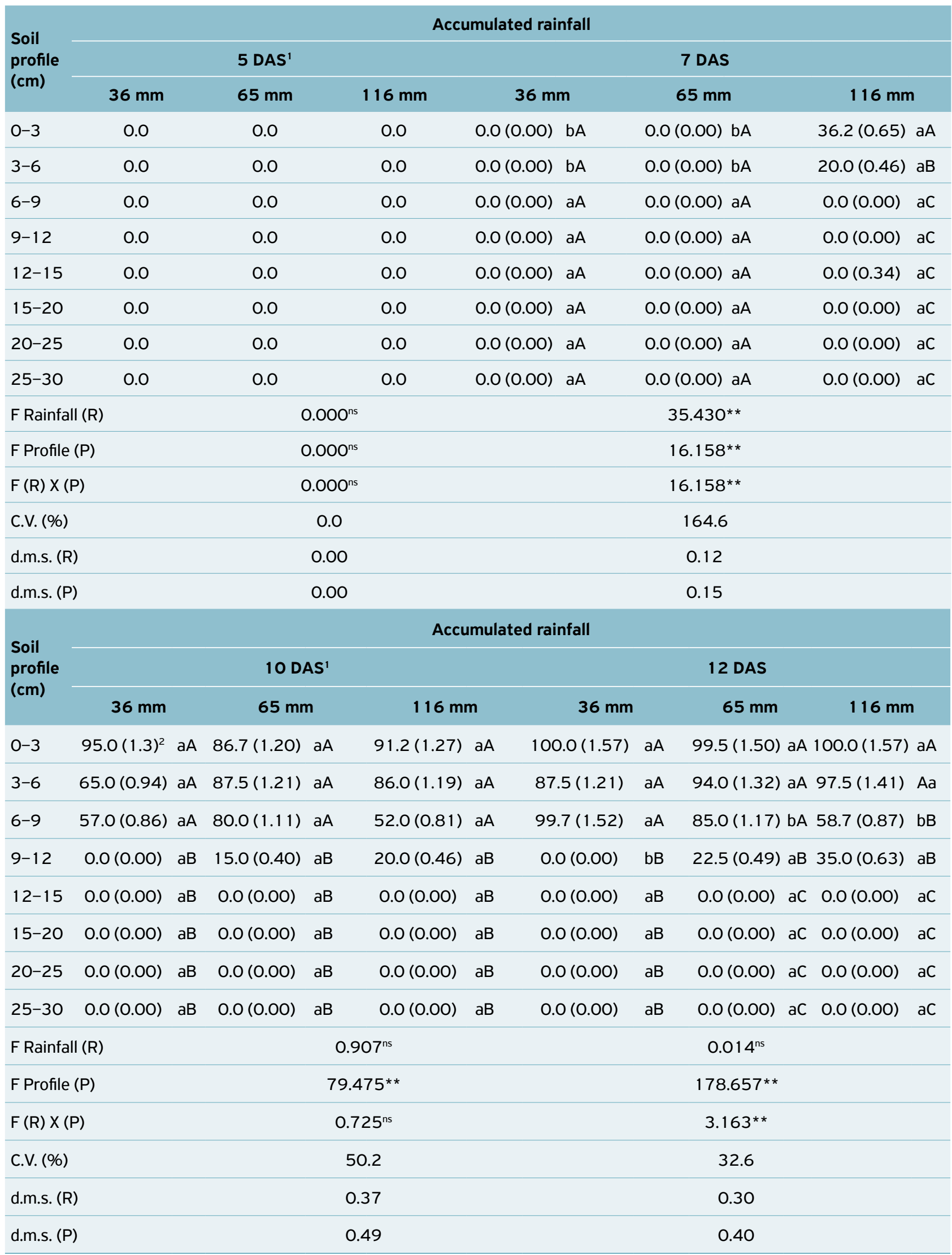

Means within a column followed by the same upper-case letter and within a line followed by the same small case letter are not significantly different at the $5 \%$ probability level according to Tukey's test. 'DAS: days after sowing; ${ }^{2}$ data in parentheses were transformed using the equation $y=\operatorname{arc} \sin [\operatorname{root}(x / 100)]$; ${ }^{*}$ significant at level $(p<0.05) ;{ }^{*}$ significant at level $(p<0.01)$. 
the better performance of cucumber as bioindicator species, which showed the presence of the herbicide in deeper layers. The mobility of the tebuthiuron was confirmed at 10 and 12 DAS with an ARD of $36 \mathrm{~mm}$, when the herbicide reached the $6-9 \mathrm{~cm}$ layer, and with ARD of 65 and $116 \mathrm{~mm}$ when it reached the $9-12 \mathrm{~cm}$ layer.

According to the results, the mobility of the tebuthiuron herbicide with the evaluated ARD is restricted to a depth of $12 \mathrm{~cm}$ due to its low leaching potential. CERDEIRA et al. (2005) collected groundwater samples from 1996 to 2003 and found no tebuthiuron; however, GOMES et al. (2001) found tebuthiuron herbicide in groundwater samples.

CERDEIRA et al. (2007) collected soil samples in 2004 and 2005 from the soil surface layer up to the depth of 120 $\mathrm{cm}$ at 180 days after tebuthiuron application, and found no measurable residues of this herbicide, and no tebuthiuron residues below soil depth of $40 \mathrm{~cm}$ at any evaluation time.

\section{CONCLUSION}

The mobility of the herbicide tebuthiuron in the soil profile of clayey soils is restricted to the depth of $12 \mathrm{~cm}$, and to the depth of $15 \mathrm{~cm}$ in sandy loam soils, regardless of the accumulated natural rainfall depth.

The use of cucumber (Cucumis sativus L.) as bioindicator plants is adequate for this type of study.

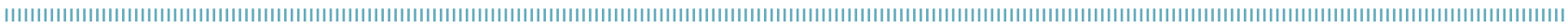
REFERENCES

BOEIRA, R.C.; SOUZA, M.D.; FERRACINI, V.L. Utilização de colunas de solo para avaliação de lixiviação de agrotóxicos. In: CONGRESO IBEROAMERICANO SOBRE GESTIÓN DE CALIDAD EN LABORATORIOS, 2., 2003, Valladolid. Resúmenes...Valladolid, ITACYL, 2003.

CERDEIRA, A.L.; DOS SANTOS, N.; PESSOA, M.C.Y.; GOMES, M.A.F.; LANCHOTTE, V.L. Herbicide leaching on a recharge area of the Guarany aquifer in Brazil. Journal of Environmental Science and Health, Part B, New York, v.4O, n. 1, p. 159-165, 2005.

.; DESOUZA, M.D.; QUEIROZ, S.C.N; FERRACINI, V.L.; BOLONHEZI, D.; GOMES, M.A.F.; ROSA, M.A.; BALDERRAMA, O.; RAMPAZZO, P.; QUEIROZ, R.H.C.; NETO, C.F.; MATALLO, M.B. Leaching and half-life of the herbicide tebuthiuron on a recharge area of Guarany aquifer in sugarcane fields in Brazil. Journal of Environmental Science and Health, Part B, New York, v.42, n.6, p.635639, 2007. http://dx.doi.org/10.1080/03601230701465593

CHRISTOFFOLETI, P. J.; LÓPEZ-OVEJERO, R. F. Dinâmica de herbicidas aplicados ao solo na cultura da cana-de-açúcar. Piracicaba: Edição dos autores, 2005. 49 p.

DEUBER, R.; NOVO, M.C.S.S.; TRANI, P.E.; ARAÚJO, R.T.; SANTINI, A. Manejo de plantas daninhas em beterraba com metamitron e sua persistência em argissolo. Bragantia, Campinas, v.63, n.2, p.283-289, 2004. http://dx.doi.org/10.1590/ s0006-87052004000200013.

DORNELAS DE SOUZA, M.; BOEIRA, R.C.; GOMES, M.A.F.; FERRACINI, V.L.; MAIA, A.H.N. Adsorção e lixiviação de tebuthiuron em três tipos de solo. Revista Brasileira de Ciência do Solo, Viçosa, v.25, n.4, p.1053-1061, 2001. http://dx.doi.org/10.1590/ So $100-06832001000400027$

EMMERICH, W.E. Tebuthiuron-environmental concerns. Journal of Rangelands, Melbourne, v.7, n.1, p.14-16, 1985.
GOMES, M.A.F.; SPADOTTO, C.A.; LANCHOTTE, V.L. Ocorrência do herbicida tebuthiuron na água subterrânea da microbacia do córrego espraiado, Ribeirão Preto - SP. Pesticidas: Revista de Ecotoxicologia e Meio Ambiente, Curitiba, v. 1 1, p.65-76, 2001.

; MATALLO, M.B.P.; LUCHINI, L.C. Monitoramento do herbicida tebuthiuron em dois solos representativos das áreas de recarga do aqüífero Guarani. Revista Brasileira de Engenharia Agrícola e Ambiental, Campina Grande, v.10, n.2, p.479-483, 2006.

INOUE, M.H.; SANTIN, A.J.; DALLACORT, R.; POSSAMAI, A.C.S.; SANTANA, D.C. Performance de associações de herbicidas em cana-de-açúcar (Saccharum officinarum) Revista Brasileira de Herbicidas, v.6, n.2, p.32-41, 2007. http://dx.doi.org/10.7824/ rbh.v6i2.50.

MATALLO, M.B.; SPADOTTO, C.A.; LUCHINI, L.C.; GOMES, M.A. Sorption, degradation and leaching of tebuthiuron and diuron in soil columns. Journal of Environmental Science and Health. Part B, Pesticides, Food Contaminants and Agricultural Wastes, New York, v. B40, n. 1, p. 39-43, 2005.

NEGRISOLI, E.; VELINI, E.D.; ROSSI, C.V.S.; CORREIA, T.M.; COSTA, A.G.F. Associação do herbicida tebuthiuron com a cobertura de palha no controle de plantas daninhas no sistema de cana-crua. Planta Daninha, Viçosa, v.25, n.3, p.621-628, 2007. http:// dx.doi.org/10.1590/SO100-83582007000300023.

OLIVEIRA, M.F.; SILVA, A.A.; FERREIRA, F.A.; RUIZ, H.A. Lixiviação de flumioxazin e metribuzin em dois solos em condições de laboratório. Planta Daninha, Viçosa, v.17, n.2, p.207-215, 1999. http://dx.doi.org/10.1590/SO100-83581999000200005.

OLIVEIRA JÚNIOR., R.S. Mecanismos de ação de herbicidas. In: OLIVEIRA JÚNIOR, R.S.; CONSTANTIN, J.; INOUE, M.H. Biologia e manejo de plantas daninhas. Curitiba: Omnipax, 2011.p.141-192. 
PIRES, F.R.; SOUZA, C.M.; SILVA, A.A.; CECON, P.R.; PROCÓPIO, S.O.; SANTOS, J.B.; FERREIRA, L.R. Fitorremediação de solos contaminados com tebuthiuron utilizando-se espécies cultivadas para adubação verde. Planta Daninha, Viçosa, v.23, n.4, p.7 1 1-717, 2005. http:// dx.doi.org/10.1590/S0100-83582005000400020

.; PROCÓPIO, S.O.; SANTOS, J.B.; SOUZA, C.M.; DIAS, R.R. Avaliação da fitorremediação de tebuthiuron utilizando Crotalaria juncea como planta indicadora. Revista Ciência Agronômica, Fortaleza, v.39, n.02, p.245-250, 2008.

RODRIGUES, B.N.; ALMEIDA, F.S. Guia de herbicidas. 6. ed. Londrina: Edição dos Autores, 2011.

SERGIO, C.; ZACARIAS, X.B.; LINCOLN, G.C.; FERNANDA, L.R.; ARMINDO, A.A.J. Levantamento físico conservacionista do Ribeirão Lavapés, Botucatu, SP. Revista de la Facultad de Agronomía, La Prata, v.22, n.2, p.170-184, 2005.
SOCIEDADE BRASILEIRA DA CIÊNCIA DAS PLANTAS DANINHAS (SBCPD). Procedimentos para instalação avaliação e análise de experimentos com herbicidas. Londrina: SBCPD, 1995.

SOUZA, E.L.C.; FOLONI, L.L.; MANTOVANI, E.C.; TEIXEIRA FILHO, J. Comportamento do tebuthiuron em solo de cultivo de canade-açúcar utilizando lisímetro de drenagem modificado. Planta Daninha, Viçosa, v.26, n.1, p.157-163, 2008. http://dx.doi. org/10.1590/SO100-83582008000100016

SPADOTTO, C.A.; GOMES, M.A.F.; HORNSBY, A.G. Pesticide leaching potential assessment in multi-layered soils. Pesticidas: Revista de Ecotoxicologia e Meio Ambiente, Curitiba, v.12, p. 1-12, 2002.

TOFOLI, G.R.; VELINI, E.D.; NEGRISOLI, E.; CAVENAGHI, A.L.; MARTINS, D. Dinâmica do tebuthiuron em palha de cana-deaçúcar. Planta Daninha, Viçosa, v.27, n.4, p.815-82 1, 2009. 